\title{
Global Warming Potential, Variable Costs, and Water Use of a Model Greenhouse Production System for 11.4-cm Annual Plants Using Life Cycle Assessment
}

\author{
Dewayne L. Ingram ${ }^{2}$ \\ Department of Horticulture, University of Kentucky, N-318 Ag Science \\ North, Lexington, KY 40546-0091 \\ Charles R. Hall ${ }^{1}$ \\ International Floriculture, Department of Horticultural Sciences, Texas \\ A\&M University, 2133 TAMU, College Station, TX 77843-2133
}

\section{Joshua Knight \\ Department of Horticulture, University of Kentucky, N-318 Ag Science North, Lexington, KY 40546-0091}

\begin{abstract}
Additional index words. floriculture crops, greenhouse production, Begonia $\times$ semperflorenscultorum
\end{abstract}

\begin{abstract}
Life cycle assessment (LCA) was used to analyze the global warming potential (GWP) and variable costs of production system components for an 11.4-cm container of wax begonia (Begonia $\times$ semperflorens-cultorum Hort) modeled in a gutter-connected, Dutch-style greenhouse with natural ventilation in the northeastern United States. A life cycle inventory of the model system was developed based on grower interviews and published best management practices. In this model, the GWP of input products, equipment use, and environmental controls for an individual plant would be 0.140 kilograms of carbon dioxide equivalents $\left(\mathrm{kg} \mathrm{CO}_{2} \mathrm{e}\right)$ and the variable costs would total \$0.666. Fifty-seven percent of the GWP and $43 \%$ of the variable costs would be due to the container and the portion of a 12-plant shuttle tray assigned to a plant. Electricity for irrigation and general overhead would be only $13 \%$ of GWP and $2 \%$ of variable costs. Natural gas use for heating would be $0.01 \%$ of GWP and less of the variable costs, even at a northeastern U.S. location. This was because of the rapid crop turnover and only heated for 3 months of a 50-week production year. Life cycle GWP contributions through carbon sequestration of flowering annuals after being transplanted in the landscape would be minor compared with woody plants; however, others have documented numerous benefits that enhance the human environment.
\end{abstract}

Production of annual bedding plants providing seasonal color in the landscape is the primary profit center for many greenhouse operations. However, the increasingly hypercompetitive markets and decreasing profit margins of these enterprises have required the continual analysis of production and marketing systems (Hall, 2010). Also, a key success factor for these industries is to examine the inseparable factors of efficient input use, cost savings, enhanced product quality, and the sustainable nature of production or

Received for publication 13 Oct. 2017. Accepted for publication 2 Jan. 2018.

This material is based on work that is supported by the National Institute of Food and Agriculture, U.S. Department of Agriculture, Specialty Crop Research Initiative, under award number 2014-51181-22372.

${ }^{1}$ Professor and Ellison Chair.

${ }^{2}$ Corresponding author. E-mail: dingram@uky. edu. and McPherson, 2012). Young foliage plant production systems in two distinct greenhouse types have also been compared using LCA (Ingram et al., 2017b). CF is expressed in GWP due to GHG emissions for a 100 -year period in units of $\mathrm{kg} \mathrm{CO}_{2} \mathrm{e}$. Thus, our objective in this study was to add to the knowledge about the range of nursery and greenhouse production systems, by analyzing the environmental impact potentials of a model production system in the northeastern region of the United States for finished annual color plants in 11.4-cm containers. In addition to providing detailed impact information of the individual components of production systems, so that growers can find ways to increase production efficiency and minimize GHG emissions, information gained from these studies should be appealing to environmentally conscious consumers (Yue et al., 2016).

\section{Materials and Methods}

A production system model for greenhouse production of an 11.4-cm wax begonia plant (Begonia ×semperflorens-cultorum Hort) was based on the best management practices for the northeastern United States. Grower interviews were conducted to validate production life cycle, input products, equipment use, heating and cooling requirements, water use, and labor hours for each operation or cultural practice. The system model consists of purchasing plugs in 288 count trays, transplanting them to $11.4-\mathrm{cm}$ containers in 12-plant shuttle trays, and growing them for 8 weeks before marketing. General greenhouse operations and energy use not specifically assigned to an operation, input, or process were designated as overheard and calculated for an 8-week portion of a 50-week cropping year and assigned to an individual plant. The greenhouse was modeled as a gutter-connected, Dutch-style house with roof and side ventilation, horizontal circulating fans, bilayer polycarbonate covering, 3.6-m sidewalls, and no evaporative cooling, in the northeastern United States. Although supplemental lighting may be used for some portion of the year, it would not be used for other portions of the year. Therefore, the GWP and cost of lighting was not separated from the estimated overhead electrical energy consumption. The average daily temperature in this region is $12{ }^{\circ} \mathrm{C}$ (U.S. Climate Data, 2017).

The $150,000 \mathrm{~m}^{2}$ of heated greenhouse space would be designed with a gutter system to capture rainfall and store it in $1000 \mathrm{~m}^{3}$ tanks. It was assumed that 6.6 plants were produced on each square meter of a concrete floor and plants were irrigated using an overhead, traveling boom.

Heating of the greenhouse would be required for 3 months and consume $5 \mathrm{~m}^{3}$ of natural gas per $1000 \mathrm{~m}^{2}$ according to the records of growers interviewed. The expected overall annual electricity use of the facility minus electricity allocated to specific operations, such as pumping water for treatment 
and irrigation, constituted unallocated electricity and was calculated to be $0.047 \mathrm{kWh} /$ plant in this model. In addition to the labor assigned to each operation, it was assumed that an additional $560 \mathrm{~h}$ of labor per 10,000 plants was invested in overall operations, such as facility management and office personnel, and proportionally assigned to an individual plant.

The substrate typically used contains $80 \%$ peat and $20 \%$ perlite by volume. It was assumed that plugs would be purchased at \$0.107 each, their CF would be insignificant, and there would be $1 \%$ plant loss during production (Ingram et al., 2017b). Three applications of a fungicide (pyraclostrobin, tetrachloroisophthalonitrile, and iprodione in rotation) would be made per crop using a sprayer with a $5-\mathrm{kW}$ gasoline pump to apply $0.00004 \mathrm{~kg}$ of product per plant and requiring 20 min per 10,000 plants per application. A plant growth regulator, $3.5 \mathrm{~L}$ of product containing $0.026 \%$ ancymidol, would be applied twice using a sprayer with a $5-\mathrm{kW}$ gasoline pump for 20 min per 10,000 plants.

Preparing substrate and plugs, filling pots, transplanting using a transplanter, and moving plants to the greenhouse floor was assumed to cost $\$ 0.03$ per plant and use 80 man-hours and 20 equipment-hours per 10,000 plants based on grower interviews. The transplanter and conveyer system would require $18 \mathrm{~kW}$ of electric motors. An electric cart would pull carts of plants from the transplanting area to the greenhouse floor at the rate of 10,000 plants in $18.3 \mathrm{~h}$. Pulling orders and loading trucks for delivery would require labor costs of $\$ 0.043$ per plant and consume $0.004 \mathrm{kWh}$ of electric cart $(5.2 \mathrm{~kW})$.

Irrigation would be provided by an overhead, traveling boom delivering a total of $120,000 \mathrm{~L}$ in 24 irrigations. A $37.3-\mathrm{kW}$ electric pump would be required. Two manhours per 10,000 plants would be invested in monitoring irrigation. Irrigation water would be pumped from a storage tank filled with rainwater capture and from a well. Irrigation water would be continuously filtered and ozonated to supply $2 \mathrm{mg}$ ozone/L and require
$36 \mathrm{kWh}$ of electricity per 10,000 plants. Filtration and ozonation was assumed to cost $\$ 0.05$ for each $3785 \mathrm{~L}$ or $\$ 0.00002$ per plant based on Raudales et al. (2016). Treatment of wastewater would require $19 \mathrm{kWh}$ of electricity per 10,000 plants and use a bacteria filter at a cost of $\$ 0.02$ per $3785 \mathrm{~L}$ gallons. Fertilization would be provided with irrigation each week at $200 \mathrm{mg} \mathrm{N} / \mathrm{L}$ from a $14 \mathrm{~N}-6.1 \mathrm{P}$ $11.6 \mathrm{~K}$ water-soluble fertilizer with ammonium nitrate-based nitrogen sources.

Inventory analysis and data collection. Life cycle inventory procedures were used to record all input products, equipment use, and other activities for a functional unit of an $11.4-\mathrm{cm}$ begonia plant in a 12-plant shuttle tray. LCA protocols were applied to the inventory following international standards, including the International Organization for Standardization [ISO (2006) (Geneva, Switzerland)] and PAS 2050 guidelines by BSI British Standards (2011). GHG emissions were determined for each input and activity, converted to $\mathrm{kg} \mathrm{CO}_{2} \mathrm{e}$ per functional unit and summed. Emissions from the manufacturing of capital goods, such as buildings and machinery, were not included in this study as per PAS 2050, Section 6.4.4.

The GWP of applied nitrogen from $\mathrm{NH}_{4}$ $\mathrm{NO}_{3}, \mathrm{P}_{2} \mathrm{O}_{5}$, and $\mathrm{K}_{2} \mathrm{O}$ fertilizers were 9.7, 1.0, and $0.7 \mathrm{~kg} \mathrm{CO}_{2} \mathrm{e} / \mathrm{kg}$ for, respectively, as previously published (Snyder et al., 2009; Wang, 2007). A GWP of each input product, including manufacturing processes and transportation, was calculated from the U.S. life cycle inventory (USLCI) database (U.S. Department of Energy, 2017) and SimaPro (Pre' North America, Inc., Washington, DC). A $1 \%$ loss of applied $\mathrm{N}$ as $\mathrm{N}_{2} \mathrm{O}$ was assumed based on research with field soils and resulted in an estimated GWP of $4.65 \mathrm{~kg} \mathrm{CO}_{2} \mathrm{e} / \mathrm{kg}$ of $\mathrm{N}$ applied (IPCC, 2006; Snyder, et al., 2009; West and Marland, 2003). The GWP of natural gas combusted in an industrial boiler and the GWP of electricity in the region were set as $2.40 \mathrm{~kg} \mathrm{CO} / \mathrm{m}^{3}$ and $0.438 \mathrm{~kg} \mathrm{CO} \mathrm{CO}_{2} \mathrm{e} / \mathrm{kWh}$, respectively, from USLCI data through SimaPro.

The substrate consisted of $80 \%$ peat and $20 \%$ perlite by volume considering a $5 \%$ shrinkage during mixing. GWP was calculated to be $0.317 \mathrm{~kg} \mathrm{CO}_{2} \mathrm{e} / \mathrm{kg}$, of which 0.100 $\mathrm{kg} \mathrm{CO}_{2} \mathrm{e}$ was from peat $(0.945 \mathrm{~kg})$ and 0.217 $\mathrm{kg} \mathrm{CO}_{2} \mathrm{e}$ was from perlite $(0.121 \mathrm{~kg})$, which included mixing and transportation as previously published (Ingram et al., 2017a). A GWP of the 12-plant shuttle trays manufactured from polystyrene using blow-mold technology was calculated to be $0.037 \mathrm{~kg}$ $\mathrm{CO}_{2} \mathrm{e} / \mathrm{kg}$ per marketable plant. This was calculated using SimaPro, assuming a material transported distance of $200 \mathrm{~km}$ and landfill disposal of used containers (Ingram et al., 2017a). The GWP of the 11.4-cm pot was similarly calculated to be $0.043 \mathrm{~kg}$ $\mathrm{CO}_{2} \mathrm{e} / \mathrm{kg}$ per marketable plant. The average $\mathrm{CO}_{2} \mathrm{e}$ emission for a range of fungicides $\left(12.50 \mathrm{~kg} \mathrm{CO} \mathrm{CO}_{2} \mathrm{e} / \mathrm{kg}\right.$ ) from data presented by Lal (2004). The average $\mathrm{CO}_{2} \mathrm{e}$ emissions from the use of growth regulators was calculated as $9.45 \mathrm{~kg} \mathrm{CO}_{2} \mathrm{e} / \mathrm{kg}$ using SimaPro.

Although labor does not contribute directly to a product's GWP, it contributes significantly to product variable costs. Labor requirements for operating equipment were calculated as 1.25 times the equipment operation hours to account for preparation and cleanup time. The Adverse Effect Wage Rate as determined by the U.S. Department of Labor (2017) was used to set the hourly wage rate of $\$ 12.69$. This represents the wage level that must be offered and paid to migrant workers by agricultural employers of nonimmigrant H-2A agricultural workers. Equipment costs per hour were representative of those reported in regional enterprise budgets for horticultural crops. Natural gas and electricity prices were established as $\$ 0.286 / \mathrm{m}^{3}$ and $\$ 0.10 / \mathrm{kWh}$ (U.S. Energy Information Administration, 2017).

\section{Results and Discussion}

A GWP for an 11.2-cm wax begonia plant was calculated to be $0.140 \mathrm{~kg} \mathrm{CO}_{2} \mathrm{e}$ from $\mathrm{GHG}$ emissions due to production protocols of the model system including the use of input products, use of equipment, and environmental controls (Table 1). The

Table 1. Global warming potential and variable costs of production components (labor, materials, and equipment operation costs) incurred during greenhouse production of an 11.4-cm wax begonia plant (Begonia ×semperflorens-cultorum) in the northeastern United States from plugs in 8 weeks.

\begin{tabular}{|c|c|c|c|c|c|c|c|c|c|}
\hline \multirow[b]{2}{*}{ Activity/components } & \multicolumn{3}{|c|}{ Materials } & \multicolumn{3}{|c|}{ Equipment use GWP } & \multirow{2}{*}{$\frac{\text { Labor }}{\text { Costs }(\$)}$} & \multicolumn{2}{|l|}{ Total } \\
\hline & (kg or unit/plant) & GWP $\left(\mathrm{kg} \mathrm{CO}_{2} \mathrm{e}\right)$ & Costs $(\$)$ & $\overline{\text { (h/plant) }}$ & GWP $\left(\mathrm{kg} \mathrm{CO}_{2} \mathrm{e}\right)$ & Costs $(\$)$ & & $\overline{\mathrm{GWP}\left(\mathrm{kg} \mathrm{CO}_{2} \mathrm{e}\right)}$ & Costs $(\$)$ \\
\hline $\begin{array}{l}\text { Plug from no. } 288 \text { and } \\
\text { transplanting }\end{array}$ & 1.0101 & 0.0074 & 0.1066 & 0.0000 & 0.0000 & 0.0000 & 0.0303 & 0.0074 & 0.1369 \\
\hline Container & 1.0101 & 0.0430 & 0.1501 & 0.0000 & 0.0000 & 0.0000 & 0.0000 & 0.0430 & 0.1501 \\
\hline Shuttle tray & 0.0842 & 0.0371 & 0.1346 & 0.0000 & 0.0000 & 0.0000 & 0.0000 & 0.0371 & 0.1346 \\
\hline $\begin{array}{c}\text { Irrigation/water } \\
\text { management }\end{array}$ & 0.0000 & 0.0000 & 0.0000 & 0.0027 & 0.0012 & 0.0003 & 0.0004 & 0.0012 & 0.0007 \\
\hline Pest management & 0.0000 & 0.0001 & 0.0027 & 0.0000 & 0.0001 & 0.0001 & 0.0002 & 0.0001 & 0.0030 \\
\hline Plant growth regulator & 0.0001 & 0.0000 & 0.0106 & 0.0000 & 0.0000 & 0.0001 & 0.0002 & 0.0001 & 0.0108 \\
\hline Pull orders and load truck & 0.0000 & 0.0000 & 0.0000 & 0.0008 & 0.0019 & 0.0035 & 0.0427 & 0.0019 & 0.0463 \\
\hline Heating (natural gas) & 0.0000 & 0.0000 & 0.0000 & 0.0001 & 0.0002 & 0.0000 & 0.0000 & 0.0002 & 0.0000 \\
\hline Electricity (overhead) & 0.0000 & 0.0000 & 0.0000 & 0.0391 & 0.0171 & 0.0038 & 0.0000 & 0.0171 & 0.0038 \\
\hline Unallocated grower/labor & 0.0000 & 0.0000 & 0.0000 & 0.0000 & 0.0000 & 0.0000 & 0.0186 & 0.0000 & 0.0186 \\
\hline Total per plant & 2.1859 & 0.1178 & 0.5491 & 0.0433 & 0.0218 & 0.0099 & 0.1067 & 0.1396 & 0.6657 \\
\hline
\end{tabular}

$\mathrm{kg} \mathrm{CO} 2 \mathrm{e}=$ kilograms of carbon dioxide equivalents. 
total variable costs for this functional unit would be $\$ 0.666$. As expected, the GWP and variable costs of this product is significantly less than a 72-count tray of foliage plant liners $\left(2.276 \mathrm{~kg} \mathrm{CO}_{2} \mathrm{e}\right.$ and $\$ 25.251$, respectively) grown in a similar greenhouse but in the southern United States (Ingram et al., 2017b).

The container would account for $30.8 \%$ of the GWP and the 12-container shuttle tray

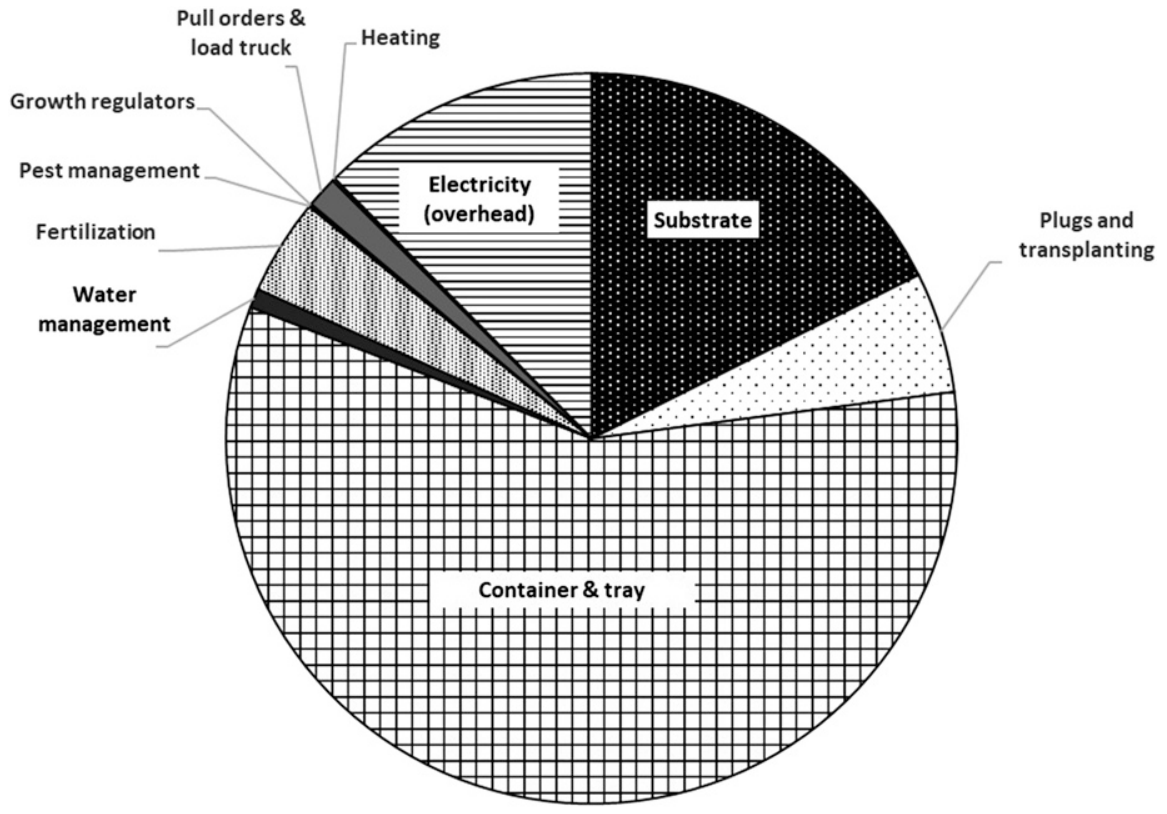

Total GWP $=0.140 \mathrm{~kg} \mathrm{CO}_{2} \mathrm{e}$

Fig. 1. Global warming potential (GWP) for production components and activities for an 11.4-cm wax begonia plant (Begonia Xsemperflorens-cultorum) modeled as an 8-week crop from plugs in a greenhouse range in the northeastern United States.

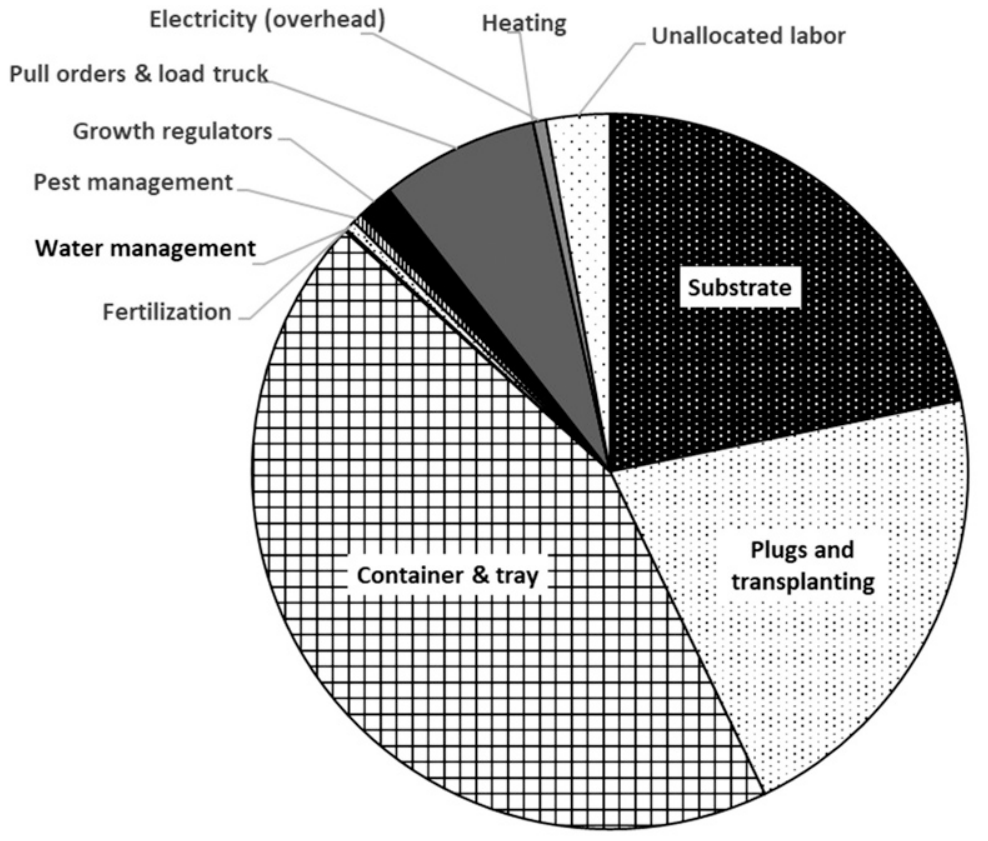

Total Variable Costs $=\$ 0.666$

Fig. 2. Variable costs for production components and activities incurred during 8-week production from plugs of an 11.4-cm wax begonia plant in a greenhouse range in the northeastern United States.
Transferring plants from the potting area to the greenhouse floor would account for $1 \%$ of GWP and $2.4 \%$ of variable costs while pulling orders and loading trucks would account for $1.4 \%$ of GWP but $7.0 \%$ of variable costs. Compared with distributing plants to the greenhouse floor, pulling orders would require more labor because of the additional steps in locating the plants, grading as necessary, cleaning containers, etc.

Fertilization would add $4.2 \%$ of GWP but only $0.45 \%$ of variable costs. Pest management and application of growth regulators combined would contribute only $0.13 \%$ of GWP and $2.1 \%$ of variable costs.

Electricity to provide irrigation and treat the $30 \%$ runoff before discharge would contribute less than $1 \%$ of GWP and variable costs. Electricity not allocated to individual operations in the model would account for $12.3 \%$ of GWP and less than $1 \%$ of variable costs. Heating for 3 months of the 50 weeks of greenhouse production, when spread across the number of crop turnovers, would have only a minor impact on GWP and variable costs. This differs significantly from the 12week greenhouse production of foliage plant liners where heating and electricity accounted for $77 \%$ of GWP (Ingram et al., 2017b). Some of these differences could also be due to the temperature sensitivity of foliage plants (i.e., the need to maintain a higher temperature than for begonia production) and the larger space utilization of the 72-count tray compared with an 11.4-cm container.

This production model would use $1.8 \mathrm{~L}$ of water for irrigation per plant. In a similar greenhouse and a stationary overhead irrigation system, the 72-count flat of foliage liners used $64 \mathrm{~L}$ of irrigation water (Ingram et al., 2017b). Compared on an area basis for the crops, the water use would be $17.25 \mathrm{~L} \cdot \mathrm{m}^{-2}$. week $^{-1}$ for this 8 -week begonia model and $35.8 \mathrm{~L} \cdot \mathrm{m}^{-2} \cdot$ week $^{-1}$ for the 12 -week foliage liner production model.

Analyzing components of a model system using LCA allows the construction of what-if scenarios that could aid in management decisions. For example, the plastic container and shuttle tray would contribute $57.4 \%$ of GWP in this model and reduce the GWP of these inputs by $10 \%$ would reduce the GWP of this begonia plant by $0.008 \mathrm{~kg} \mathrm{CO}_{2} \mathrm{e}$ or $5.7 \%$. Assuming a closed water system and no related environmental impact, reducing fertilizer use by $10 \%$ would only reduce the overall plant GWP by $0.0006 \mathrm{~kg} \mathrm{CO}_{2} \mathrm{e}$, or $0.4 \%$, and reduce variable costs by $\$ 0.0003$. Reducing the cost of the substrate by $10 \%$ would reduce the total variable costs by $2 \%$ (\$0.14). Labor accounts for $18 \%$ of total variable costs in this model and increasing the labor wage rate to $\$ 15.00$ per hour (as being proposed as the minimum wage in several states), would increase the cost of the 11.4 begonia by $\$ 0.014$ or $2 \%$. A straight $25 \%$ increase in the wage rate would result in a cost increase of $\$ 0.02$ or $3 \%$. With a decreasing profit margin on some plants, even a small increase or decrease in an important cost item could affect profitability. 
When assessing the potential ecosystem services, such as carbon sequestration provided by plants, herbaceous annual flowering plants do not make a long-term impact compared with woody plants. However, like foliage plants, flowering annual plants do contribute to human health and well-being in other ways through their aesthetic value and ecosystem services, such as reduced storm water runoff and improved air quality (Hall and Dickson, 2011).

\section{Literature Cited}

Boston Consulting Group. 2009. The business of sustainability: Imperatives, advantages, and actions. 31 Mar. 2017. <bcg.com>.

BSI British Standards. 2011. Specification for the assessment of the life cycle greenhouse gas emissions of goods and services. BSI British Standards (Publicly Available Specification) PAS 2050:2011

Hall, C.R. 2010. Making cents of green industry economics. HortTechnology 20:832-835.

Hall, C.R. and M.W. Dickson. 2011. Economic, environmental, and health/well-being benefits associated with green industry products and services: A review. J. Environ. Hort. 29(2):96103.

Hall, C.R. and D.L. Ingram. 2014. Production costs of field-grown Cercis canadensis L. 'Forest Pansy' identified during life cycle assessment analysis. HortScience 49:1-6.

Hall, C.R. and D.L. Ingram. 2015. Carbon footprint and production costs associated with varying the intensity of production practices during field-grown shrub production. HortScience 50:402-407.

Ingram, D.L. 2012. Life cycle assessment of a field-grown red maple tree to estimate its carbon footprint components. Intl. J. Life Cycle Assess. 17:453-462.

Ingram, D.L. 2013. Life cycle assessment to study the carbon footprint of system components for Colorado blue spruce field production and landscape use. J. Amer. Soc. Hort. Sci. 138:3-11.

Ingram, D.L. and C.R. Hall. 2013. Carbon footprint and related production costs of system components of a field-grown Cercis canadensis $\mathrm{L}$.
'Forest Pansy' using life cycle assessment. J. Environ. Hort. 31(3):169-176.

Ingram, D.L. and C.R. Hall. 2014a. Carbon footprint and related production costs of system components for a field-grown Viburnum $\times j u d d i$ using life cycle assessment. J. Environ. Hort. 32:175-181.

Ingram, D.L. and C.R. Hall. 2014b. Life cycle assessment used to determine the potential environment impact factors and water footprint of field-grown tree production inputs and processes. J. Amer. Soc. Hort. Sci. 140:102-107.

Ingram, D.L. and C.R. Hall. 2015a. Carbon footprint and related production costs of pot-in-pot system components for red maple using life cycle assessment. J. Environ. Hort. 33(3):103-109.

Ingram, D.L. and C.R. Hall. 2015b. Using life cycle assessment (LCA) to determine the carbon footprint of trees during production, distribution and useful life as the basis for market differentiation. Acta Hort. 1090:35-38.

Ingram, D.L., C.R. Hall, and J. Knight. 2016. Carbon footprint and variable costs of production components for a container-grown evergreen shrub using life cycle assessment: An east coast U.S. model. HortScience 51:989994.

Ingram, D.L., C.R. Hall, and J. Knight. 2017a. Comparison of three production scenarios for Buxus microphylla var. japonica 'Green Beauty' marketed in a No. 3 container on the west coast using life cycle assessment. HortScience 52:357-365.

Ingram, D.L., C.R. Hall, and J. Knight. 2017b. Modeling global warming potential, variable costs, and water use of young plant production system components using life cycle assessment. HortScience 52:1356-1361.

Intergovernmental Panel on Climate Change (IPCC). 2006. Guidelines for national greenhouse gas inventories. Vol. 4. Agriculture, forestry and other land use. Chapter 11: $\mathrm{N}_{2} \mathrm{O}$ emissions from managed soils, and $\mathrm{CO}_{2}$ emissions from lime and urea application. 13 July 2017. <http://www.ipcc-nggip.iges.or.jp/public/ $2006 \mathrm{gl} / \mathrm{vol} 4 . \mathrm{html}>$.

International Organization for Standardization (ISO). 2006. Life cycle assessment, requirements and guidelines. ISO Rule 14044:2006. ISO, Geneva, Switzerland.

Kendall, A. and E.G. McPherson. 2012. A life cycle greenhouse gas inventory of a tree production system. Intl. J. Life Cycle Assess. 17(4):444-452.

Lal, R. 2004. Carbon emissions from farm operations. Environ. Intl. 30:981-990.

Rankin, A., A. Gray, M. Boehlje, and C. Alexander. 2011. Sustainability strategies in U.S. agribusiness: Understanding key drivers, objectives, and actions. Intl. Food Agribus. Mgt. Rev. 14(4): $1-20$.

Raudales, R.E., P.R. Fisher, and C.R. Hall. 2016. The cost of irrigation sources and water treatment in greenhouse production. Irr. Sci. 35: $43-54$.

Snyder, C.S., T.W. Bruulsema, T.L. Jensen, and P.E. Fixen. 2009. Review of greenhouse gas emissions from crop production systems and fertilizer management effect. Agr. Ecosyst. Environ. 133:247-266.

Southern Nursery Association. 2013. Best management practices: guide for producing nursery crops. 3rd ed. SNA, Acworth, GA.

U.S. Climate Data. 2017. 19 Sept. 2017. <https:// www.usclimatedata.com/climate/>.

U.S. Department of Energy. 2017. U.S. life-cycle inventory database. Natl. Renewable Energy Lab. (NREL). 17 Apr. 2017. <https://www. lcacommons.gov/nrel/search>.

U.S. Department of Labor. 2017. Wages in agriculture. 5 Sept. 2017. $<$ https://www.foreignlaborcert. doleta.gov/adverse.cfm>

U.S. Energy Information Administration. 2017. 5 Sept. 2017. <https://www.eia.gov/state/ print.php?sid=NJ>.

Wang, M.Q. 2007. GREET 1.8a spreadsheet model. 13 Nov. 2015. <http://www.transportation.anl. gov/modeling_simulation/index.html $>$.

West, T.O. and G. Marland. 2003. Net carbon flux from agriculture: Carbon emissions, carbon sequestration, crop yield, and land-use change. Biogeochemistry 63(1):73-83.

Yue, C., B. Campbell, C. Hall, B. Behe, J. Dennis, and H. Khachatryan. 2016. Consumer preference for sustainable attributes in plants: Evidence from experimental auctions. Agribusiness 32(2):222-235. 